\title{
II Międzynarodowa konferencja naukowa „Wielokulturowe śro- dowisko historyczne Lwowa w XIX i XX wieku". Uniwersytet Rzeszowski, 2 -3 października 2003 r.
}

W dniach 2-3 października 2003 roku w Uniwersytecie Rzeszowskim odbyła się II Międzynarodowa konferencja naukowa nt. „Wielokulturowe środowisko historyczne Lwowa w XIX i XX wieku”. Konferencja została zorganizowana z inicjatywy Profesora Jerzego Maternickiego, kierownika Zakładu Historii Historiografii i Metodologii Historii, Instytutu Historii Uniwersytetu Rzeszowskiego.

W konferencji uczestniczyli przedstawiciele z kilku ośrodków uniwersyteckich Polski (Uniwersytetu Łódzkiego, Uniwersytetu Marii Curie-Skłodowskiej w Lublinie, Uniwersytetu Mikołaja Kopernika w Toruniu, Uniwersytetu Adama Mickjewicza w Poznaniu, Uniwersytetu Rzeszowskiego, Uniwersytetu Warszawskiego, Akademii Pedagogicznej w Krakowie) oraz szkół wyższych z Ukrainy (Lwowa, Drohobycza, Iwano-Frankowska). Swój udział w konferencji zgłosili także przedstawiciele niemieckiego środowiska historycznego z ośrodków akademickich w Bielefeld i Getyndze.

Podczas obrad konferencji jej uczestnicy próbowali odpowiedzieć na kilka zasadnjczych pytań związanych z rozwojem nauk historycznych w XIX i XX wieku oraz kształtowaniem się Iwowskiego środowiska historycznego. Rozważania uczestników tego spotkania naukowego były pewnego rodzaju kontynuacja tematów prezentowanych w czasie obrad I Międzynarodowej konferencji na ten temat, która odbyła się w 2002 roku.

Konferencje rozpoczał referat profesora Jerzego Maternickiego pt. „Złota księga historiografii lwowskiej XIX i XX w. - koncepcja dzieła, jego kształt metodologiczny i wydawniczy". Autor nakreślił w niej istotę prac nad wspomnianym dziełem, które jego zdaniem powinno powstać we współpracy międzynarodowej, co wynika ze specyfiki ówczesnego środowiska naukowego Lwowa.

W dalszej części spotkania tematyka obrad dotyczyła następujących problemów:

- polscy i ukraińscy historycy - wzajemne relacje,

- Środowisko historyczne Uniwersytetu Lwowskiego a historycy niemieccy i austriaccy,

- dydaktyka i dydaktycy historii XIX i XX wieku,

- historycy wychowania $i$ ich zainteresowania badawcze,

- problematyka badawcza polskich i ukraińskich historyków,

- szkoły badawcze,

- instytucjonalizacja lwowskiej historii,

- źródła do badania dziejów lwowskiego środowiska historycznego w archiwach Lwowa.

Obradom towarzyszyła interesująca dyskusja, podczas której jej uczestnicy podejmowali zagadnienia rozwoju i funkcjonowania Jwowskiego, wielokulturowego środowiska uczonych. Dyskutowano o nie zawsze łatwych relacjach wielonarodowego środowiska i ujmowaniu dziejów przez jego przedstawicieli w perspektywie narodowej. W wygloszonych opiniach akcentowano także konieczność nowego, tj. wielokulturowego spojrzenia na niektóre zagadnienia z przeszłości lwowskiego ośrodka naukowego.

Ważnym punktem tej konferencji było kolejne zebranie członków „Międzynarodowego zespołu badawczego - Wielokulturowe środowisko historyczne Lwowa w XIX i XX wieku”. Członkami "Międzynarodowego zespołu" sa historycy i przedstawiciele różnych subdyscyplin historycznych, w tym także historycy wychowania. W pracach zespołu oraz organizowanych konferencjach środowisko historyków wychowania reprezentują: z Uniwersytetu Rzeszowskiego - prof. dr hab. Andrzej Meissner i z Uniwersytetu Mikołaja Kopernika - dr hab. Władysława Szulakiewicz, prof. UMK. Podczas spotkania omawiano dalsze etapy badań nad podjętym tematem i formy ich realizacji. Sporo miejsca w dyskusji zajęla sprawa zaproponowanej ,Listy historyków” zakwalifikowanych do „Złotej księgi historiografii lwowskiej XIX i XX wieku". W tej kwestii poczyniono także ustalenia dotyczace sposobu opracowywania wybranych do tego dzicła historyków. 
Organizatorzy konferencji zapewnili uczestników, iż materiały pokonferencyjne zostaną opublikowane oraz poinformowali o terminie kolejnej konferencji, która planowana jest na wrzesień 2004 roku.

Whadystawa Szulakiewicz

\title{
Zapowiedzi
}

\author{
Wrocław, 22 - 23 kwietnia 2004 - Międzynarodowa Konferencja Naukowa nt. \\ „Europa wspólnotą narodów. Edukacja międzykulturowa na przełomie \\ wieków (XIX - XX, XX - XXI)"
}

Organizatorami konferencji są Zakład Historii Edukacji i Zakład Pedagogiki Społecznej Uniwersytetu Wrocławskiego.

Obrady dotyczyć będa m.in. następujących zagadnień szczególowych:

- funkcje szkoły $\mathrm{j}$ innych instytucji edukacyjnych $\mathrm{w}$ odniesieniu do zadań ważnych dla edukacji regionalnej, wielokulturowej i międzykulturowej;

- kształcenie nauczycieli i studentów kierunków pedagogicznych i nauczycielskich w perspektywie makro- i mikroglobalizacji oraz regionalizacji;

- organizacja kształcenia na różnych jego poziomach, obejmującego uczniów wywodzacych się ze środowisk odmiennych pod względem kulturowym, ze szczególnym uwzględnieniem kształcenia poza granicami kraju pochodzenia.

Poznań, 24-27 czerwca 2004 - Międzynarodowa Konferencja Naukowa nt. „Bohaterowie w historii i pamięci społeczeństw europejskich. Postaci upamiętniane przez współczesnych mieszkańców różnych części Europy"

Głównym organizatorem konferencji jest Zakład Dydaktyki Historii Uniwersytetu im. Adama Mickiewicza w Poznaniu. Obrady koncentrować się będa wokół następujących zagadnień:

- wspólnota doświadczeń historycznych i jej wpływ na kształtowanie świadomości kulturowej współczesnych społeczeństw europejskich;

- bohaterowie europejscy, narodowi, lokalni jako świadectwo pamięci współczesnych społeczeństw europejskich;

- bohaterowie doby transformacji społecznej w pamięci młodzieży i jej rodziców z Europy Środkowo-Wschodniej. 